\title{
Literary and Linguistic Dimensions of the Middle Ages
}

\section{Paula-Andreea Onofrei}

Actes du colloque international "Journées de la Francophonie", XXIIIe édition, Iaşi, 29-30 mars 2018, Textes réunis par Felicia Dumas, Éditions Junimea, Iaşi, 2019

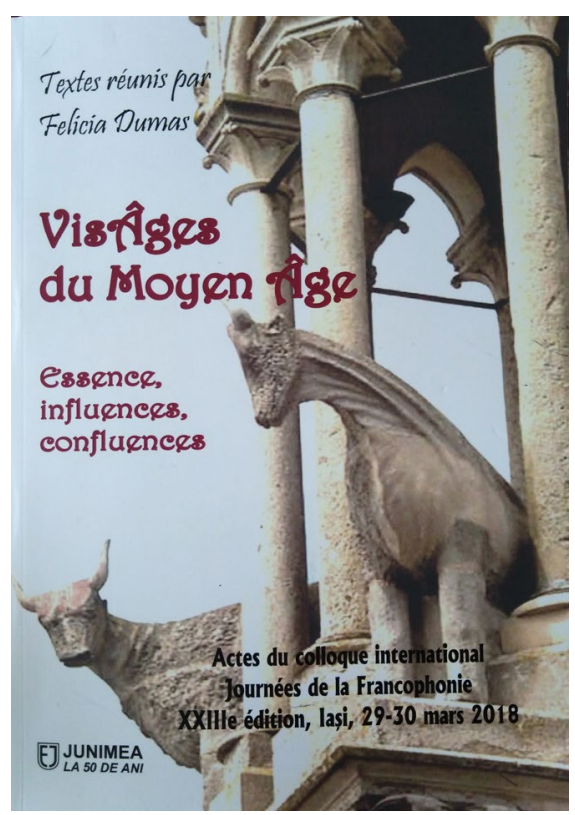

The texts of this volume actually represent the scientific research papers that were presented at the XXIII edition of the International Annual Francophone Colloquium, organized by the Department of French from the Faculty of Letters of "Alexandru Ioan Cuza" University from Iaşi in 2018.

Firstly, under the coordination of Prof. Felicia Dumas, these texts were reunited and published in this book, the approached topics being varied, all of them gravitating around the topic of the Middle Ages: literature, architecture, the religious habits of the Christians who go in pilgrimage, the translation of the Psalms or medieval poets.

Secondly, as far as the structure of this book is concerned, we have identified two sections, the first being "Le Moyen-Âge littéraire, ses mystères et ses trésors" [The Literary Middle Ages, Mysteries and Treasures], the second is called "Langue, philosophie et civilization françaises au Moyen Âge" [ The French Language, Philosophy and Civilisation of the Middle Ages], the curious reader has the pleasure of finding 18 various authors that have been grouped under the first heading, while the second heading benefits from the same number of authors, this time different from the first group. 
Thirdly, the authors of these texts are researchers from France, the United States of America, Maroc and Romania, the largest category being represented by professors from the great universities of Bucharest, Cluj, Iaşi and Suceava who have dedicated themselves to the study of literary, cultural, linguistic, translation-related or religious topics, all of them connected to the heterogenous, complex and enriching topics that put in light the Middle Ages. In a nutshell, the above-mentioned sections represent two red threads of scientific investigation which have become traditional for this international event: literary discourse and linguistic analysis, largely speaking cultural analysis.

To conclude, this book is an invitation to analysis, research, introspection and discovery about the literary and linguistic dimensions of the Middle Ages, the essence of this book being the challenge of embarking in a surprisingly beautiful cultural study about the medieval period, addressed not only to specialists, but also to all the people that are eager to enlarge their cultural horizon. 